\title{
PHYSICAL NEEDS OF THE RAILWAYS UNDER GOVERN- MENT CONTROL
}

\section{By Julius H. Parmelee}

Railway congestion may result from two wholly distinct forms of inadequacy, so far as concerns equipment; an inadequate supply of equipment, or inadequate utilization of equipment already in service. Having first ascertained which particular form of inadequacy is responsible for some specific experience in congestion, it becomes possible to determine what shall be the proper remedy. Government control over the American railway system, which became effective as the calendar year 1917 was drawing to a close, was made necessary partly by the congested condition of railway traffic, especially in the eastern section of the United States. To arrive at an estimate of the equipment and other facility needs of the railways while under government control, it is advisable briefly to review recent traffic history, to ascertain what steps led up to the President's proclamation taking over the railways, and finally to attempt a forecast of the probable traffic developments and physical needs of the near future.

For the sake of clearness and convenience, certain terms will be used throughout this article to convey certain specific meanings, as follows: "Period of government control" will be used to include such period after the declaration of peace as may be assigned (either by Congressional or Presidential action) for the retention of the lines. The term "railway facilities" throughout the article will denote the general railway plant, including roadway and track, bridges, stations and other structures, with the sole exception of equipment. "Equipment" will refer to the movable part of the plant, including locomotives and cars of all kinds. "Motive power" will refer to locomotives, while "rolling stock" will be used to apply to cars as distinguished from locomotives. Inasmuch as the discussion will center almost wholly on freight traffic problems, "rolling stock" will indicate freight cars unless otherwise specified.

The railways of the United States are under constant obligation not only to maintain their facilities and equipment, including 
repairs, retirements, and ordinary replacements, but also to add such new facilities and new equipment each year as will enable them to keep up with the growth of traffic. There is a clear distinction between maintenance of the railway plant at normal level, and such improvements and betterments as represent additions to the plant. The cost of maintenance is an operating expense, met from current revenues and chargeable to "maintenance of way and structures" and "maintenance of equipment" accounts. The cost of additions is a capital charge, whether the new facilities and equipment are paid for out of surplus, earnings or are financed by the sale of securities. The distinction is not only one of accounting, but also reflects the purposes for which maintenance and additions are carried out. Maintenance work is designed to keep a railway in condition to meet the normal traffic demands that, judging by past records, will be made upon it; new additions are made to care for the added traffic that is expected to develop from the growing needs of a community, or to promote economy and efficiency in operation. These distinctions should be borne clearly in mind, as they have a definite bearing on any discussion of physical railway needs.

\section{Growth of Traffic, Equipment and Facilities to 1917}

Growth of railway traffic has been astonishingly great in recent years. From 1908 to 1915 the annual increase in tons of revenue and non-revenue freight carried one mile, or ton-miles, was less than 4 per cent, while the number of passengers carried one mile, or passenger-miles, increased less than 2 per cent per year. Since 1915, however, both forms of traffic have grown by leaps and bounds. The calendar year 1916 showed an increase in freight traffic over the fiscal year 1915 (ended June 30) of about a third, the increase being from a little over 300 billion ton-miles to about 400 billion ton-miles. This was the growth of a period of eighteen months. The calendar year 1917 showed an increase over 1916 of not less than 10 per cent, which would place the 1917 traffic in the neighborhood of 450 billion ton-miles. For the thirty-month period from July 1, 1915, to December 31, 1917, this represents an increase from about-300 billion to 450 billion ton-miles, or 50 per cent. Similarly, passenger-miles increased from 32 billion in the fiscal year 1915 to 35 billion in the calendar year 1916, an increase of approximately 10 per cent in eighteeen months. The passenger 
business in 1917 was unusually heavy, partly owing to the demands of war travel, and partly to heavy troop movements. While exact figures are not as yet available regarding the passenger traffic of 1917 , it was approximately 15 per cent greater than in 1916, which would make it not less than 40 billion passenger-miles. This is an increase for the period from 32 billion to 40 billion passengermiles, or about 25 per cent.

We have thus presented an extraordinary picture of traffic increases as between the annual periods ended July 1, 1915, and December 31, 1917, as follows:

Ton-miles, from 300 billion to 450 billion a year, or 50 per cent.

Passenger-miles, from 32 billion to 40 billion a year, or 25 per cent.

The significance of these astounding figures will be made apparent in our discussion of physical needs.

Railway mileage has increased but slowly during the past few years, the average annual increase being about a thousand miles. This refers to miles of line, or first main track. Increase in additional trackage, such as second, third and fourth tracks, yard tracks, and sidings, constructed to enable railways to handle a more intensive traffic, has been more rapid than in miles of line. Additional trackage has been growing recently at the rate of nearly 2,500 miles a year. Applying these annual rates to the thirty-month period from July 1,1915 , to December 31,1917 , the best available figures make it appear that miles of line increased about 2,500 miles, and additional tracks about 6,000 miles. While this represents a considerable amount of new construction, it is an increase in line mileage of only 1 per cent, and in additional track mileage of about 5 per cent. Recollection that freight traffic increased 50 per cent during the same period and passenger traffic 25 per cent will lead to a realization of the additional traffic burden thrown on each mile of line in 1917 as compared with 1915. In fact, traffic density as measured by ton-miles and passenger-miles per mile of line increased 48 per cent in the case of freight traffic and 24 per cent in the case of passenger traffic. This burden fell primarily on the railway staff, secondarily on the terminal facilities, motive power, and rolling stock, freight and passenger, and lastly on the other facilities included in the railway plant.

While the growth of traffic was throwing this greatly increased 
burden onto the railways, was there a corresponding increase in the amount of equipment in service and available to handle the traffic? Detailed figures are not available to December 31,1917 , but it is possible to approximate an answer to this query. During the eighteen months from July 1, 1915, to December 31, 1916, the increase in number of steam locomotives in railway service was less than 2 per cent, the increase in freight cars was considerably less than 1 per cent, and in passenger cars approximately 1 per cent. The year 1917 offers a most complex record as to the construction and distribution of new equipment, and as will be shown a little later, the demands of our allies and of our own armies in France drew off much of the production originally intended for the American railways. It probably does not overstate the case to say that as a whole 1917 did not add over 1 per cent to the supply either of locomotives, or of freight and passenger cars, which would make the number in service on December 31, 1917, greater than on July 1, 1915, by about 3 per cent in the case of locomotives and about 2 per cent in the case of cars. Thus with an added 2 or 3 per cent of equipment, and an additional 1 to 5 per cent of trackage, the railways in 1917 were handling 25 to 50 per cent more traffic than in 1915 ! $^{1}$

The answer to what seems at first sight a most puzzling riddle may be found partly in the fact that 1915 was a year of low traffic, partly in the monthly freight efficiency reports issued by the Railroads' War Board beginning with April, 1917. Such great increases in traffic as have just been indicated could not have been handled merely by taking up the slack of 1915 , but must have been met either by greatly increasing railway facilities or by utilizing existing facilities to a much greater degree than formerly. We have seen that mileage and equipment showed very moderate rates of growth from 1915 to 1917, while traffic was growing by tremendous leaps; the first alternative, that of increased facilities, is therefore untenable. That the second alternative must more nearly approximate the correct solution is confirmed by the War Board efficiency reports and by the testimony of close students of the period. During the first eight months of the War Board's operations (April to November

${ }^{1}$ Owing to the continually increasing size and capacity of equipment, and to improvements in other facilities, railway facilities do not need to increase proportionally so fast as traffic. My emphasis is merely on the very wide margin here shown between the different rates of increase. 
inclusive) the average load per loaded car increased from 24.8 tons in 1916 to 27.1 tons in 1917 , or 9.3 per cent; the number of tons hauled per train increased from 626 tons to 672 tons, or 7.3 per cent; finally, the daily mileage of locomotives increased 1.9 per cent. This resulted in a saving of 32 million train-miles and 1,350 million carmiles. That is, even with heavier loading, which might logically have tended to slow up the movement of trains over the tracks, the drive for efficiency inaugurated by the Railroads' War Board had its result in greater carloads joined together in heavier trains, traveling longer distances each day than formerly. Combining these different factors into one, each freight locomotive during the seven-month period of 1917 hauled a greater amount of traffic, measured in terms of ton-miles, by 11.1 per cent, than during the corresponding period of 1916, while similarly each freight car carried a greater traffic by 9.9 per cent. Available statistics on passenger traffic efficiency are far less definite and complete than those for the freight traffic, but with the same equipment limitations as in the case of freight, on the one hand, and similar increases in passenger traffic on the other hand, the use of each locomotive and car in the passenger service must also have increased greatly.

The comparisons of the preceding paragraph are all of 1917 with 1916 , and portray considerable gains in efficiency in 1917. We have already seen that the year 1916 showed great traffic increases as compared with 1915, and with but slight additions to equipment and other facilities. It seems safe to assume, therefore, that operating efficiency in 1916 was at a higher level than in 1915, and this in spite of the fact that 1915 was a year of business depression, when railway facilities were not being utilized to the fullest. If the efficiency of 1916 was greater than that of 1915 , while the efficiency of 1917 was considerably greater than in 1916, it follows that the two-year gain in efficiency was more than considerable.

The foregoing review of growth of traffic, of equipment, and of facilities to 1917 brings us to the prospects and needs of the period of government control. At the outset we are confronted with the annoying fact that difficult as it may be to picture the immediate past and grasp the present, it is almost impossible to outline the future, even in the most sketchy fashion. What will be the period of the war, how will its needs and demands shape themselves, what new alignments of men and materials will be necessary before the 
clarion of peace is sounded? These and many similar queries call for answer before the attempt be made to prophesy the future needs of the railways. Yet some idea of the railway future is necessary, if our transportation facilities are to be kept up to their mark and do their share toward the prosecution of the war and toward the later general reconstruction.

\section{EQUiPMENT Problems in 1917}

Before turning to the future, it may not be unfruitful to glance for a moment at the equipment problems confronting the American railways in 1917. The annual output of locomotives for domestic use has not been below 2,000 for many years, and has risen much higher in some years. In 1916 it was slightly over 4,000. Anything short of 2,500 would appear insufficient to take care of replacement and renewal needs. It is clear, of course, that a certain amount of construction each year serves merely to fill up such gaps in equipment in service as are due to loss by fire or wreck, consignment to the scrap heap because no longer fit for service, and obsolescence. Replacements and renewals are for the most part charged to operating expenses. Over and above replacement demands are the demands for entirely new equipment to meet the needs of increasing traffic; and the cost of such equipment is a capital charge. In 1917 the number of locomotives built for domestic use was only 2,600 , or less than half the total output for the year, the balance being allotted to the French and Russian governments and to the American army in France. These 2,600 engines for domestic order hardly more than met the normal replacement needs of the railways. With freight and passenger traffic in 1917 much higher than the 1916 and 1915 levels, and with locomotive construction hardly sufficient to meet replacement needs, it is clear that what motive power was in service in 1917 must have been driven at top speed to accomplish the necessary results.

The situation with regard to freight and passenger cars was not so bad, although it was serious enough. The normal replacement need for freight cars is probably in the neighborhood of 100,000 cars a year. In 1916, construction for domestic use amounted to 135,000 cars, while in 1917 it dropped slightly below 120,000 . That is, the domestic supply of freight cars in 1916 and 1917 added about 55,000 cars above replacement needs to equipment already in service, or 
something over 2 per cent. Passenger car construction for domestic needs averages normally not less than 2,500 cars. In 1916 it was 1,800 and in 1917 about 2,000, or below normal. Production of freight cars for foreign order in 1917 was about 32,000, while passenger car construction for foreign use was negligible.

The statistics of the foregoing paragraph may be summarized in the statement that with a freight and passenger traffic running much greater than in 1915, the supply of new freight cars for domestic use was only slightly greater than sufficient for replacement needs, certainly hardly equal to providing for the abnormal traffic requirements of 1917 , while the supply of new locomotives and passenger cars was not only below normal in 1917 , but was probably insufficient to meet normal requirements for replacement.

With this review of 1917 conditions in mind, and having before us also the growth of traffic and of equipment and other facilities from 1915 to 1917 , we may now turn to the prospects for the period of government control. Such a survey of future prospects must rest partly on traffic possibilities and partly on the possibility of keeping up the supply of new equipment, rails, bridges, ballast, ties and countless other materials that are included under the head of facilities.

\section{Traffic Possibilities during Period of Government Control.}

First, as to traffic possibilities. In the matter of passenger service, it may be assumed that under government control of transportation facilities and operation the needs of passenger travel will be very largely subordinated to the movement of absolutely necessary war materials and other necessary freight, food and fuel. In Great Britain every effort has been made since the outbreak of war to reduce passenger travel upon the railways. To effect reductions low rates have been cancelled, special service has been cut down or abolished, free baggage and other privileges have been largely withdrawn, and every effort made to induce the general public to refrain from unnecessary travel. When these various devices did not produce the fullest results desired, the Railway Executive Committee in 1917 took the radical step of increasing passenger fares 50 per cent by a stroke of the pen, the avowed object of the move being to decrease travel rather than to increase revenues. Still other restrictions are in prospect. Whatever steps may be 
taken in the United States to stem the tide of passenger travel during the war, it is safe to predict that serious and earnest attempts will be made to keep it down to a reasonable level, if possible, and that the demands of the traveling public for such facilities as new passenger stations and other conveniences, and for passenger equipment (especially for special equipment such as Pullman, drawing, observation, restaurant cars, and the like) will not be met until the freight service has been taken care of, and that means not at all during the progress of the war. The history of the principal warring nations has given us a striking picture of official effort to keep down passenger travel, and we may reasonably assume that the United States will soon be a figure in the same picture. In fact, efforts have already been made, both under private management and government control, to make travel less attractive by providing less trains and fewer special services and conveniences per train. Passenger traffic may be kept stationary, or may even be reduced if that proves practicable.

The problem of freight transportation is wholly different. If the United States is to be a significant factor in winning the war, her transportation system must be tuned up to highest pitch, both to meet the normal and legitimate demands of our economic activities, to supply vital munitions and supplies to our troops across the seas, and to assist our allies with the essential food and other supplies that will hold up their hands in the final stages of the conflict. Freight traffic will probably continue at its maximum, then, during the remainder of the war period. The maximum to date was the freight record of 1917 , which was in the neighborhood of 450 billion tonmiles. In fact, the war demands for transportation in 1918 and later years may go above this maximum of 450 billion ton-miles. True, the traffic will be different in many respects, will be in different directions, and will be made up of different articles and in different proportions from that of normal times, but that the speeding up of our war machine will lay demands on our transportation system far above any yet made seems almost beyond question. Let us assume at the beginning, therefore, that traffic demands during the period of government control will be more likely to increase than to decrease. 


\section{Government Utilization of Equipment and Facilities}

How will these demands be met? By utilizing the existing railway plant to fuller capacity than ever before, or by increasing the plant? Probably both methods will be called into play. In the first place, government unification should lead to many improvements in the utilization and coördination of railway facilities. The President's address to Congress on January 4, 1918, stated this clearly in the following words:

It had become unmistakably plain that only under government administration can the entire equipment of the several systems of transportation be fully and unreservedly thrown into a common service without injurious discrimination against particular properties. Only under government administration can an absolutely unrestricted and unembarrassed common use be made of all tracks, terminals, terminal facilities and equipment of every kind. Only under that authority can new terminals be constructed and developed without regard to the requirements or limitations of particular roads. But under government administration all these things will be possible,-not instantly, but as fast as practical difficulties, which cannot be merely conjured away, give way before the new management.

The routing privileges heretofore held by the shipper, under the provisions of the Interstate Commerce Act, can be withdrawn by the Director General of Railroads if he deems desirable, and a hampering element in freight transportation be removed thereby. As a matter of fact, the congested situation in the east has already compelled the waiving of this privilege in many instances. At first sight it may not appear clear why the routing privilege hampered traffic, but second thought will bring into relief the fact that congestion could not be relieved at terminal or junction points, or at gateways into the east from west and south, so long as shippers were directing that certain freight shipments should move into or through those very terminals, junctions, or gateways. It actually happened during the summer of 1917 that the Railroads' War Board pleaded with large shippers of certain food supplies to relieve congestion at the Pittsburgh gateway by diverting their traffic through the southeast. The War Board could not accomplish this because the law. tied their hands; the food administration took up the matter and the diversion was accomplished. Under government control freight can be routed with little reference to the preferences of the shipper; the chief consideration will be to move freight, and to move it quickly. 
Again, government control can unify the supply and distribution of motive power and equipment, making of it virtually a national pool. The Railroads' War Board in 1917 pooled several kinds of freight car equipment by meeting demands for cars from whatever source happened to be available. Motive power was also pooled to a limited degree in December. Congestion in the Pittsburgh district grew so serious that 100 western freight locomotives were commandeered by the War Board and placed in eastern service, while to relieve the coal situation in the West Virginia district 25 locomotives were drawn from southeastern roads and turned over to two roads operating in that district. These efforts, excellently designed as they were, could be but partial solutions of the problem of congestion. The government can organize an extensive pool of motive power and of freight equipment without delay, friction, or any of the hampering restrictions that may accompany deals between separate roads. In fact a step in this direction was taken by Director General McAdoo in January, when he directed American locomotive builders to deliver to specific eastern lines all locomotives completed during the months of January, February and March for railway order, regardless of the roads for which they were under construction. It was estimated that this would release 700 locomotives for almost immediate service in the east during the three-month period, only a part of which had actually been ordered by eastern roads.

Further, the Railroads' War Board pooled certain forms of freight traffic, notably the lake coal pool of June, the tide-water coal pool of July, and also iron ore pools at the lake ports. By agreement, shippers of coal and iron ore patriotically waived their individual identities for the time being and delivered their products at a common point or points, to be drawn against for whatever purpose seemed most needful. Shippers of other goods also threw their goods into what were virtually common pools of their kind of product. But while the War Board met with considerable success in the pooling of traffic, they were prohibited by law from pooling freight revenues, and this prohibition was a bar to the fullest success of their efforts. Roads that lost traffic in 1917 through pooling operations lost revenue as well, and while losses were incurred without protest by many roads, the inequity of the situation spelled failure for any widespread extension of pooling measures. The 
Director General is hampered by no anti-pooling or anti-trust laws, and the guarantee to each road of its normal net income makes it, for the time being, a matter of little moment how, in what directions, and by what routes traffic is collected, forwarded, pooled, or otherwise disposed of.

Thus it becomes clear why the government, as the controller of the railway system, will be subject to none of the hampering restrictions which undoubtedly had their share in bringing about the events that resulted in the President's proclamation.

Not only can cars be pooled and distributed without restriction, but all the related and complex questions of car supply, of demurrage charges, of free time for loading and unloading, and other perplexing problems underlying car service, can be solved at one stroke by the government. Several steps have already been taken in that direction, as in the rules fixing demurrage rates on a sliding scale that become almost prohibitive after a week, and instituting definite restrictions as to free time for loading and unloading. The Director General may conceivably travel farther along the same line before the period of government control is terminated. Here, too, the Railroads' War Board through its important sub-committee, the Commission on Car Service, had attempted a solution of the problem with definite results. Freight congestion is largely a matter of inadequate car supply and uneven car distribution as between localities. The War Board's reports of total car shortage throughout the United States in 1917 throw light on the results attained by the Board through the Car Service Commission. From May 1 the total car shortage, that is, cars for which there was demand but no immediately available supply, fell rapidly to September 1 , then reacted quickly to a high level on November 1 . This reaction was partly seasonal, but probably represented also in part the rising tide of traffic offered.

The Railroads' War Board met also with considerable cooperation from shippers in their campaign to increase car loading. Rules governing minimum weights were modified by the roads, and many shippers agreed to sink the identity of their goods and combine similar products from different factories in common carloads. The result of this campaign is reflected in the increased carload averages of 1917 already referred to, amounting to nearly 10 per cent. 
As to making the present supply of motive power and rolling stock available, then, the government will have virtually a free hand. The only hampering factor may be found in the fact that during 1917 the pressure of traffic, the shortage of labor, and the high cost of materials kept some roads from maintaining their equipment at the highest level of repair. This applies more specifically to motive power than to cars, and also in some degree to track maintenance.

The question of the adequacy of maintenance work is extremely difficult of solution. That the maintenance level in 1917 was not sufficient to the heavy traffic of that year may be admitted, but the reasons are a matter of some discussion. The cost of transportation increased 28.9 per cent during the first eleven months of 1917, while maintenance costs increased only 11.1 per cent, maintenance of equipment increasing 14.9 per cent and maintenance of way 6.6 per cent. This comparison is only suggestive, inasmuch as labor and materials enter into transportation and into maintenance in different proportions, yet it has a certain significance. It seems reasonable to consider the scarcity of labor, the high cost of materials, and the terrific pressure of war traffic which forced equipment to remain in service when it might ordinarily have been shopped, as the predominant causes for the relatively low maintenance of 1917. Railway shop labor was unusually mobile, owing to the competition of higher wages in munitions and other factories, and flowed into other industries with appalling ease, some railway shops turning over their forces two or three times during the year. This shortage of shop labor had an especially disastrous effect on the maintenance of equipment.

This disposes of the problem of inadequate utilization of equipment and brings us to the more difficult problem of the supply of equipment and other facilities, and necessary additions thereto. This problem introduces factors so complex and so vast that we can hardly attempt more than a brief enumeration of the factors and a statement of their general relationship to the question as a whole.

\section{Needed Equipment and Facilitites tnder Government Control}

To begin with, it must be clear that a living organism must either grow or degenerate. The transportation system is a part of the economic body of a people; it furnishes the economic arteries and pumps goods through those arteries. It must live and grow, or the 
people's progress is doomed. We have seen that the past two and a half years have added little to the facilities of the roads, compared with the great increase in traffic. We have also seen that traffic will continue at a high level, perhaps higher than in 1917 , and that the general condition of railway equipment and facilities at the beginning of 1918 is on some roads below par. These various realizations lead necessarily to the conclusion that new facilities and new equipment must be added under government control and in considerable amounts, if the railways are to perform their full share in the war.

In the earlier analysis of maintenance and additions, we saw that the former is chargeable to operating expenses, while the latter is a capital item that may be charged to surplus or provided for by means of new securities. As to railway maintenance work during the period of government control, that should proceed on a fully adequate level. This evident fact is recognized in the legislation now before Congress (which may become law before this is in print), which specifically provides for adequate maintenance and depreciation charges. ${ }^{2}$ These should take care of war time requirements for repairs to equipment and facilities, for replacements, and for ordinary renewals. As expenditures of this nature are chargeable to operating expense, they will be guaranteed by the federal government during the period of control. Under these conditions, there should be no reason why the railways cannot keep up their plant to a fair degree of efficiency, barring only the war time exigencies of the supply of labor and of materials.

Railways never stop improvement work. Even under the uncertain financial and operating conditions of the last six months of 1917 , the roads invested about $\$ 200,000,000$ in their properties, in large measure for the purpose of bringing their plant nearer the point of most efficient service. We may assume that during the period of government control the railways will so far as possible continue their custom of putting a portion of net earnings back into

2 The language of the proposed Senate bill is as follows: "The President is further authorized to make in such agreement all reasonable provisions for the maintenance, repair, and renewals of the property for the depreciation thereof and for the creation of necessary reserve funds in connection therewith, to the end that at the termination of federal control the property shall be returned to each carrier in substantially as good repair and in substantially as complete equipment as at the beginning of federal control." 
their plant, and will invest part of the net operating income (the so-called "standard return" of the law) guaranteed them by the government, in their properties in the shape of additions to facilities and equipment. The standard return as provided in the proposed bill amounts to something over $\$ 900,000,000$ a year. There should be added to this an amount of from $\$ 50,000,000$ to $\$ 100,000,000$ of net income from other sources. Out of the sum of the standard return and this net income the roads must take care of war taxes, interest and other fixed charges, and must meet dividend requirements. A large part of what balance is left will undoubtedly be invested in their plant, in the form of additions and betterments. Many of the weaker roads will have no balance for improvements. so that improvements out of the standard returns will necessarily represent amounts expended by the more prosperous roads out of their own balances on their own properties. Even for strong roads, the money available for additions and betterments out of the standard return will almost certainly be insufficient for necessary additions to the plant during the period of control, and this will be the case, a fortiori, with the roads that have no balance. In other words, the weaker roads certainly, and the stronger roads probably, will be forced to secure new capital for needed additions to their plants.

While there is no absolute distinction between improvement work financed by sale of securities and that paid for from net earnings, yet improvements charged to earnings are usually of the kind represented by increasing the weight of rail, the size of cars, the weight and tractive power of locomotives, and adding more ballast, more ties, and the like-in short, an aggregate of many small improvements; while improvements financed by security issues are usually large-scale additions to the plant, such as the construction of new lines or branches, the purchase at one time of a hundred new locomotives or a thousand new cars, or the construction of a completely new terminal.

If the foregoing reasoning is correct it follows that considerable new capital must be raised during the period of government control, and that such new capital must be expended upon the many additional facilities that the demands of war traffic and general war conditions will call for. Briefly summarized, such facilities will comprise principally the following: 
Terminal facilities. These are needed as much as any other kind of facility.

Additional tracks, especially in terminal yards and at concentration points.

Additional lines into port terminals as developed, to new shipbuilding plants demanded by war needs, and to training camps, embarkation stations, quartermaster depots, and the like. Considerable work of this nature was carried on in 1917; it will be needed in much greater degree as the participation of the United States in the war grows greater.

Improved shopping and other working facilities These are needed to keep equipment in order, to conserve man-power, and to enable more work to be produced by each man.

Increased motive power. Even with the locomotives of the American railways in one gigantic pool, and with the diversion of passenger locomotives into freight service, the demands will probably exceed the available supply. High-powered locomotives capable of hauling heavy freight trains will be especially needed, and it will be absolutely essential to add engines of this type to railway equipment.

There must also be a considerable addition to the freight car equipment. The roads will need a considerable number of coal and ore cars, also other freight cars of many kinds.

What will be the aggregate amount and total cost of new facilities and equipment needed by the railways during each year of government control, whether paid for out of standard return or from new capital issues? Clearly any attempt at estimating either the physical units needed, or their aggregate cost, will be but an approximation. Yet we may assume that capital must be forthcoming during each year of government control for 3,000 new miles of track of all kinds-say 500 miles of main line, and 2,500 miles of additional tracks, yard tracks and sidings-and that the demand for new equipment over and above renewal needs will amount to 2,000 locomotives and 50,000 freight cars. The cost of these facilities, and of other facilities that may be required, may be estimated roughly as follows:

500 miles of line @ \$35,000 ...................... \$17,500,000

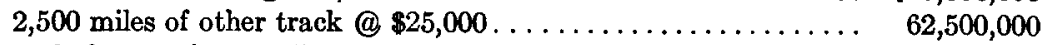

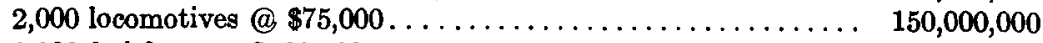

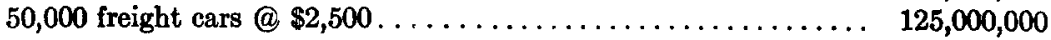

Other facilities, not less than ................. 200,000,000

Total ................................ \$555,000,000 
These rough estimates are all conservatively made, with due regard to current prices and prevailing labor conditions and wages. For example, in arriving at $\$ 25,000$ as the average cost of laying a mile of track, no account was taken of the original cost of the land, but merely of the cost of rails, ties, ballast, and track fastenings, the cost of grading and filling, and a very moderate estimate of the labor cost of laying the rail, as follows:

Rail (100 lbs. per yd.) 157 tons @ $\$ 40 \ldots \ldots \ldots \ldots \ldots \ldots \ldots \ldots . \ldots \ldots 6,280$

Ballast ( $2 \mathrm{ft}$. deep, $7 \mathrm{ft}$. wide) 2,740 cu. yds. @ $\$ 1 \ldots \ldots \ldots \ldots \ldots \ldots, 2,740$

Ties, $2,000 @ \$ 1.00 \ldots \ldots \ldots \ldots \ldots \ldots \ldots \ldots \ldots \ldots \ldots \ldots \ldots . \quad 2,000$

Track fastenings (frogs, switch fastenings, tie plates, bolts, etc.).... $\quad 2,000$

Grading, filling, etc. . . . . . . . . . .

Labor cost per mile ........................... $\quad 5,980$

Total................................. $\$ \mathbf{\$ 2 5 , 0 0 0}$

Miles of line have been estimated at $\$ 35,000$ per mile, to allow for cost of land and for buildings that may need to be erected. This is a very low average.

In brief, the best attempt at a guess - for it is nothing more at present-leads to the opinion that the railways of the United States, while under the control of the federal government, will not only be under the necessity of adequately maintaining their equipment and other facilities, including all repairs, renewals, and replacements, with proper depreciation charges, but will also put into their plant each year an amount certainly not less than $\$ 500,000,000$ - probably more - that will represent additions and improvements to plant. Maintenance charges will be cleared through the operating expense accounts. The cost of additions and betterments must be borne in large part by the issuance of new securities. How these securities shall be financed is no concern of the present inquiry; what does concern us is that for capital account the railways must expend not less than half a billion a year on their properties during the period of government control. This amount is if anything moderate and conservative; only a small part of it can come out of the standard return, while a considerable part must be financed in the open market. It would seem to follow as a logical conclusion that the greater the standard return allowed to the railways, the smaller the amount for which special financing arrangements must be made by the Director General of Railroads. The railways may safely be 
expected to invest the largest possible proportion of their standard return in their properties, while the Director General will certainly keep the aggregate of railroad financing at a minimum consistent with efficient operation. Whatever the results of these various efforts, it seems reasonable to conclude that the aggregate amount of capital needed each year will more likely be above $\$ 500,000,000$ than below that figure, and furthermore, that a large proportion of this annual amount will call for the issue of new securities.

Note.-Since this article went to press, the Director General of Railroads has issued blank forms to all'railways, requesting that they be filled out with statistics as to the needs of the roads for new equipment, for additions and betterments, and for new extensions of road or branches. The returns made on these forms, when compiled, will throw a flood of light on the problem which I have attempted to picture in its broad outlines.-J. H. P. 